\title{
Indoor comfort in presence radiant exchanges with insolated glassed walls and local acclimatization to increase indoor comfort conditions
}

\author{
Mauro Cannistraro ${ }^{1 *}$, Michele Trancossi ${ }^{2}$ \\ ${ }^{1}$ Department of Architecture, University of Ferrara, Italy \\ ${ }^{2}$ ACES, Sheffield Hallam University (UK); CEDITA Research Centre by Romaero (RO)
}

Corresponding Author Email: mauro.cannistraro@gmail.com

https://doi.org/10.18280/ti-ijes.620104

Received: 12 January 2018

Accepted: 16 March 2018

\section{Keywords:}

thermal comfort, home automation systems, radiative exchanges, ISO7726, ISO7730, Mean radiant temperature, Peltier-cells, localized acclimatization, punctual air conditioning

\begin{abstract}
The years ' 60 have been the starting point on an important R\&D activity on the technologies for increasing the indoor comfort conditions. This activity produced related standards, such as ISO7730 an important technological research on domotics and different sensors for controlling indoor acclimatization parameters (temperature, humidity, air speed, etc.) at room level. They produced automatic controls and home automation systems allow managing and control acclimatization at room level. These technical solutions still present difficulties in managing the comfort conditions in large open-space office environments. The thermal uniformity problems are accentuated by the presence of large glassed surfaces. Such architectural conditions generate an uneven thermal distribution because of solar radiation that generates some consequent levels of localized discomfort. It is then evident that an effective optimization of the comfort conditions is much more important when we consider that this architectural design is often used in offices and other working environments. Different shading solutions have been studied with limited success. Previous research activities have introduced a new physical parameter defined as "local mean radiant temperature" that allows a better evaluation of comfort conditions inside large open space environments. This intuition produces an effective local acclimatization system, which grants an effective localized control of comfort conditions in large environments with large glassed surfaces. After an effective analysis of different methods for evaluating the comfort conditions according to actual standards, it evaluates the difference and the influence of the distance from the radiating surface. In conclusion, an effective solution for improving the thermal distribution This plant is realized by two fundamental subsystems: a Wi-Fi sensing subsystem that senses airspeed and temperature and an active conditioning system made by active reversible Peltier cells. The sensing system pilots the active local acclimatization inside the "open-space" environment. In this way, it increases the comfort conditions and the air quality with remarkable energy saving with respect to any traditional air-conditioning plant. The nature of the Peltier cells produces the same effect of a micro heat pump that produces localized and punctual HVAC. An effective increase in comfort conditions has been evaluated by means of the traditional parameters, such as PMV and PPD in different conditions of work.
\end{abstract}

\section{INTRODUCTION}

The core of building acclimatization is created by the joint action of two different elements [1]: the envelope including opaque and transparent external surfaces that exchange heat with the exterior environment, and air conditioning that allows regulating temperature, humidity an airspeed inside the environment. Their coupled action determines both the energy performance of the building (also at single room level) [2] and the indoor comfort conditions for the occupants [3]. The actual state of industrial R\&D has produced an important evolution in terms of home automation system and climatic regulation [4-5]. They fit perfectly the usual needs of homes and traditional buildings, in which a thermal regulation at room level can control acclimatization and comfort needs [6]. On the contrary, there are still present problems related to the control of thermal distribution in large open-space environments [7-8], which increase in presence of large glassed surfaces which are oriented in south direction [9]. The irregularity of both the solar source and the consequent solar eating contribution deals with important irregularities in the solar induced radiant contribution [10-11]. It can generate local discomfort conditions because of daytime radiant solar heating and nighttime cooling [12]. In addition, it must be remarked that these discomfort situations are often neglected by traditional thermal monitoring systems, which measures temperature in one or more point of the room [13-14]. It can be obtained the average temperature in a room and thermal balances can be consequently performed [15]. Large open-space spaces can present relevant differences in terms of indoor temperature between different areas [16]. Sometimes, these temperature differences generate convective air circulation that reduces the comfort [17].

On a thermal point of view, it is possible to measure an average temperature that meets the general criteria for the energy fluxes balance [18]. Otherwise, a large environment 
can present local temperatures that vary throughout the space and present different values from the average one.

It must be remarked that the goal of an air conditioning plant is to ensure global conditions of temperature, airspeed and relative humidity that ensure the thermo-hygrometric comfort conditions for the occupants in any position inside the room. To do this it is necessary to consider the influence of the radiant heat exchange on the comfort condition and perception of indoor temperature [19-20]. The radiant heat exchange between the body and surrounding surface can account up to 10 times higher than the temperature of the air, in determining the thermal loads and, consequently the comfort conditions [21-22].

The manufacturers such as Daikin, Panasonic and Mitsubishi Electric have developed R\&D activity on air conditioning systems in order to increment the comfort inside buildings and defining new methods for a better management of the air conditioning processes [23]. They have developed solutions that satisfy the needs of the largest part of potential customers, which are based on room sensors and consequent control systems. In addition, it has been produced new air conditioning architectures with multiple independent fan units which can be independently regulated for improving the comfort conditions in complex environments [24].

It must be remarked that indoor comfort conditions in terms of temperature, humidity and air speed, are influenced by both individual psychology and the sense of satisfaction which is generated by the environmental conditions. It is then evident that the comfort conditions are generated by a mix of thermohygrometric physical parameters and individual sensations. In the case of office spaces, it must be remarked that individual satisfaction for the environmental condition may also have a direct influence on the work efficiency [25].

\section{PROBLEM FORMULATION}

Large commercial and directional buildings usually have an external envelope with large glassed surfaces. On one side they allow an excellent lightening of the indoor environment especially in south Europe and tropical area. On the other side glassed surfaces produce a high solar radiant load.

It has been observed that they can generate local variation of temperature and the solar radiation can varies significantly the wellness conditions during the day. This problem is evident during both daytime in summer conditions (with an effective increase of perceived heat) and during nighttime in winter conditions. According to actual standards [26-27], indoor comfort conditions can be determined by mean of the predicted mean vote (PMV) and predicted percentage of dissatisfied (PPD). Scientific literature presents many algorithms that allow determining the indoor comfort conditions in presence of radiant exchanges [28-35].

The effect on the thermal comfort, of the solar radiation that crosses through surfaces of the walls in glass, for a person sitting nearby has been investigated by Cucumo et al. [36], Khamporn and Chaiyapinunt [37] and Cannistraro [38], which obtained by tests in a test chamber, with the objective of evaluating Predicted Mean Vote (PMV) and predicted percentage of dissatisfied (PPD). They clearly demonstrate that the mean radiant temperature, PMV and PPD depends on the solar radiation transmitted through the glassed surface, and by the temperature of the surface glazed area.

\section{A PUNCTUAL ACCLIMATIZATION SYSTEM}

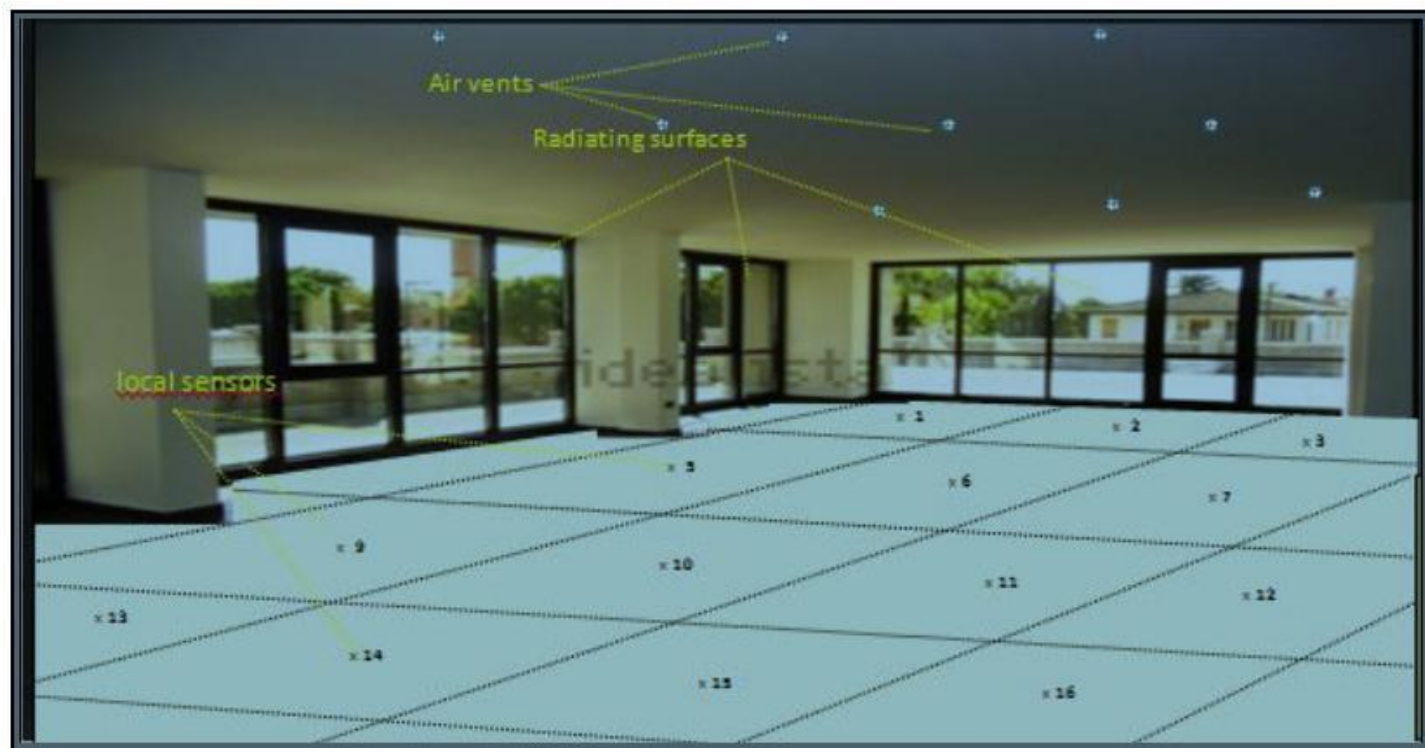

Figure 1. Representation of an "Open-space" work environment with large glassed surfaces

This paper analyses a new plant, which has been specifically conceived to produce an effective punctual regulation of the parameters that influences comfort conditions.

The study considers an "open space" work environment, (Figure 1) which is characterized by the presence of a continuous glass envelope surface facing west.

The plant is composed by a network of sensors placed on the ground. It includes a traditional air-conditioning which is governed
A plant air-conditioned, driven by an automation system, introduce the treated air through adjustable vents.

A network of micro heat pumps based on Peltier cells has been introduced to allow an effective local regulation of air temperature and humidity.

In this way, it is created a combined HVAC system that allows general acclimatization at room level and local adaptation of the climatic parameters which allows an effective increase of local comfort. 


\subsection{Peltier cells}

A Peltier element is a thermoelectric heater/cooler that acts like a micro heat pump. It is based on Seebeck work, which discloses that two dissimilar metals connected at two different junctions create a micro voltage when they are hold at two different temperatures [39].

Peltier realized, in 1834 , that the inverse effect is possible as well. If a voltage is applied to a thermocouple a temperature difference will be initiated between the junctions.

A heating or cooling effect of the junction is created depending on the direction of the current. In 1855 the dependency between the temperature change and the current has been demonstrated by Lord Kelvin who, by applying thermodynamics, established the relationship between temperature and current.
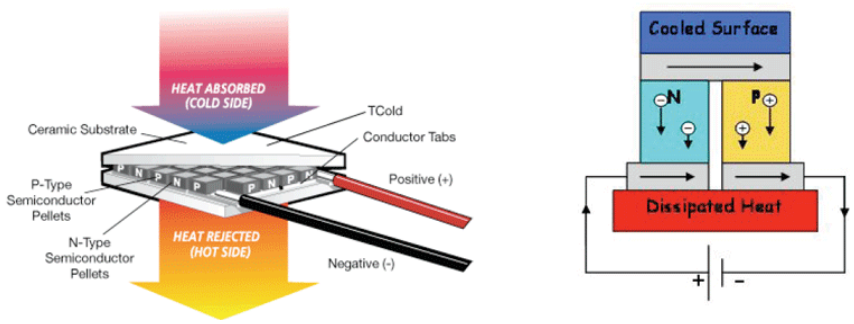

Figure 2. Sample structure of a Peltier cell (Brandeis University, MA, USA)

The formulation of the Peltier effects is given by

$$
\dot{Q}_{h}=S_{m} T_{h} I+0.5 I^{2} R_{m}-k_{m}\left(T_{h}-T_{c}\right)
$$

In which $S_{m o g}, R_{m}$, and $K_{m}$ are the Seebeck coefficient, electrical resistance, and thermal conductance of the TEC.

It is then evident that it ensures two different actions:

- Heating/Cooling - When an adequate current crosses Peltier cells, they act as refrigerator on one side and heater on the other Cells can work if we supply the necessary current that will pass through them.

When one of the joints of the thermocouple will start heating, the second one will start cooling. It appears evident that Peltier cells produce a cooling effect without compression and consequent noise.

- Cells for Generation of Electric Energy - When Peltier cells are thermally excited, they generate electric voltage which is proportional to the temperature difference.

Electric generators may either consist of a single Peltier cell or a group of them.

\subsection{Peltier cell refrigeration}

Performances of the Peltier cells as a refrigerator can be determined.

The ideal COP value is the Carnot efficiency, without losses due to heat or electrical conduction.

The ideal efficiency is given by

$$
\eta_{c}=\frac{T_{C}}{T_{H}-T_{C}}
$$

and the COP of the plant is

$$
C O P=\frac{\left(\alpha_{p}-\alpha_{n}\right) I T_{C}-\left(T_{H}-T_{C}\right)\left(K_{p}-K_{n}\right)-I^{2} \frac{R_{p}+R_{n}}{2}}{\left(\alpha_{p}-\alpha_{n}\right) I\left(T_{H}-T_{C}\right)+I^{2}\left(R_{p}+R_{n}\right)}
$$

These considerations will allow determining and analyzing the effectiveness of Peltier cells refrigeration.

\subsection{Effects of punctual refrigeration on comfort}

The PMV index predicts the mean response of a larger group of people according the ASHRAE thermal sense scale:

The PMV index is expressed by P.O. Fanger [40] as

$\mathrm{PMV}=(0.303 \mathrm{e}-0.036 \mathrm{M}+0.028) \mathrm{L}$

In which $\mathrm{L}$ represents the thermal load, which can be defined as the difference between the internal heat production and the heat loss to the actual environment.

It is estimated for a person at comfort skin temperature and evaporative heat loss by sweating at the actual activity level.

Figures 3 and 4 shows the trends of the experimental values of the temperatures, $\left[{ }^{\circ} \mathrm{C}\right]$ and Solar radiations $\left[\mathrm{W} / \mathrm{m}^{2}\right]$, during daytime.

High values of the mean radiant temperature, can generate higher values of PMV and PPD, but if they exceed a certain value they can produce uncomfortable conditions.

In literature in the field thermal comfort in presence of radiating surfaces, different formulas have been proposed for the calculation of the mean radiant temperature.

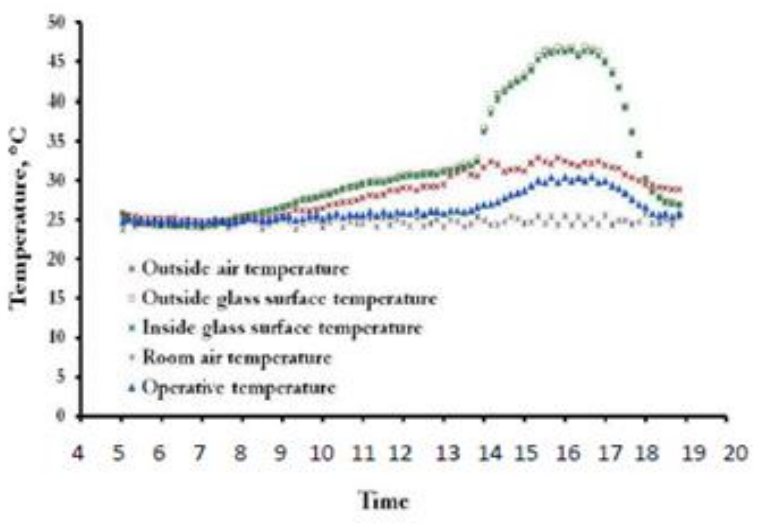

Figure 3. Experimental values of temperature [36]

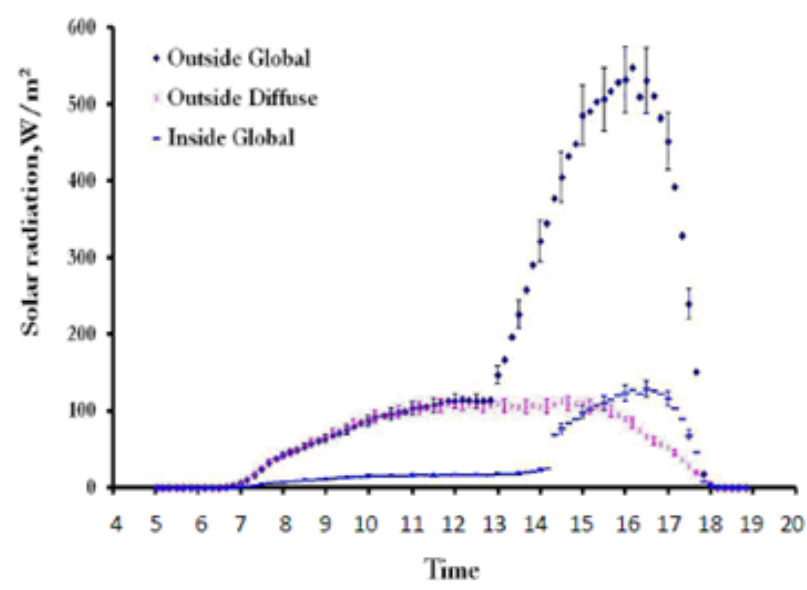

Figure 4. Experimental values of Solar radiation [36] 


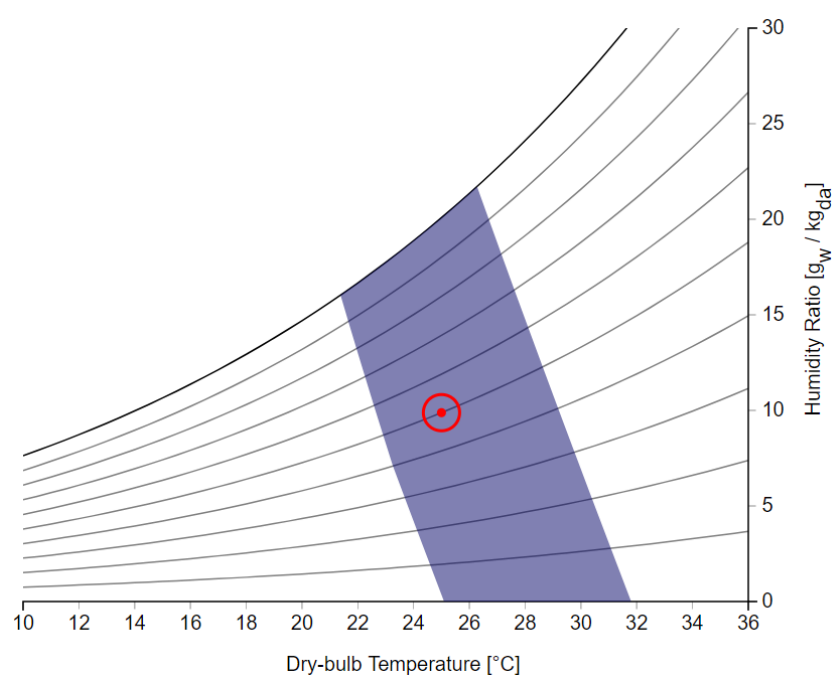

Figure 5. Summer comfort condition range with respect to temperature and humidity conditions (evidenced in gray)

The expression most used is provided by the equation

$T_{m r}^{4}=\frac{\sum_{i=1}^{b} s_{j} T_{j}^{4}}{\sum_{j=1}^{b} S_{j}}$

Recent works on the thermal comfort in presence of radiating surfaces have been produced by Kamporn [36], and Cannistraro et al. [37]. They show that local radiant mean temperature assumes different values in relation to the distance of the point from any radiating surfaces.

Cannistraro at al. proposed a new formula for estimating the local radiant mean temperature, $T_{m r l}[41-42]$ :

$$
T_{m r l}^{4}=\frac{\sum_{i=1}^{6} \frac{F_{i, j}}{f_{a p i}} \cdot \frac{s_{j}}{d_{j}} \cdot T_{j}^{4}}{\sum_{i=1}^{6} \frac{F_{i, j}}{f_{a p i}} \cdot \frac{s_{j}}{d_{j}}}
$$

Values of the Factors of view, $F_{i, j}$ can be calculate with the equation proposed by Rizzo [28] and Cannistraro [29] and adopted by the actual regulations on the thermal comfort inside the buildings ISO 7726 [25], and ISO 7730 [26].

\section{MODEL AND ANALYSIS}

This paper analyses an "open-space" indoor environment. It has a large glassed surface with west orientation. For a preliminary calculation it is assumed that people inside is in standing position, with metabolic activity coefficient of 1 , and clothing coefficient 0.75 .

For the glass--wall surface, it has been hypothesized the value of temperature $\mathrm{T}_{\mathrm{p}}=60^{\circ} \mathrm{C}$.

The values of local radiant temperature, $\mathrm{T}_{\mathrm{mrl}}$, and PMV and PPD, were calculated for each of the 16 points (see Fig.1) of the environment "open-space", in which you ran the study.

The evaluations were performed assuming for the value of incident solar radiation $\left(\mathrm{I}=500 \mathrm{~W} / \mathrm{m}^{2}\right)$, value typical of the summer periods in Italian locations, assuming for the absorption coefficient of glass-wall, the value 0.7 .

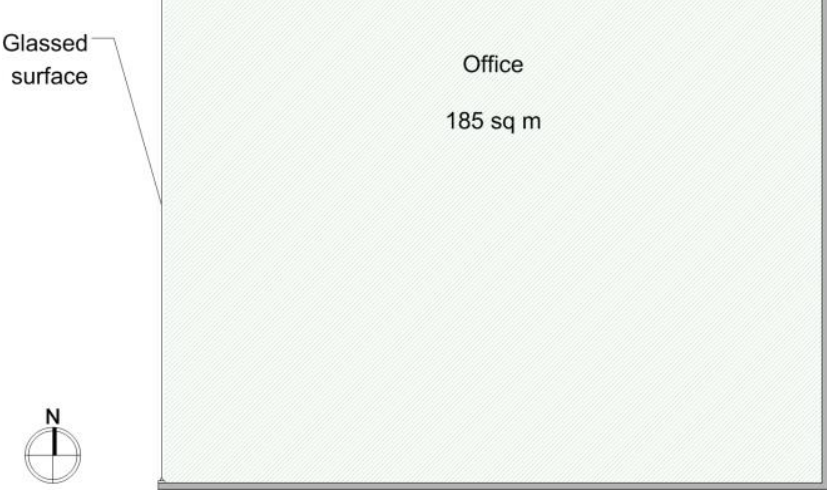

Figure 6. Sample of the considered environment

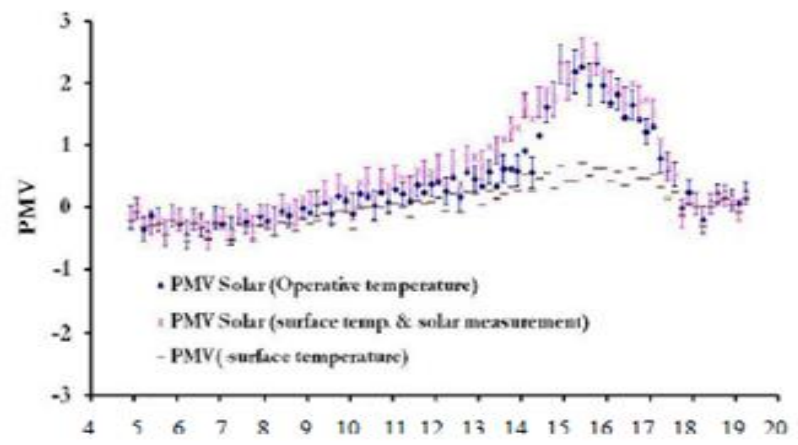

Figure 7. Obtained PMV parameters [36]

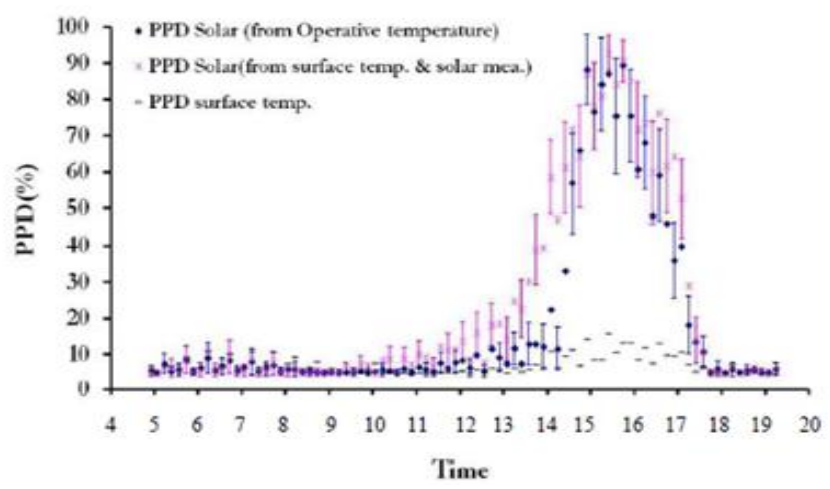

Figure 8. PPD parameters [36]

Figures 6 and 7 show the trends of PMV and PPD, which have been obtained by computational models that use the operating temperature and the experimental values of the surface temperature of the window interested by solar irradiation daytime variable values.

\section{COMFORT AND WELLNESS ANALYSIS}

If a Peltier-cell based local acclimatization system is introduced, it must provide an acceptable microclimate and maintain adequate wellness conditions. According to the above theoretical analysis about comfort conditions, the environmental quality of a space is determined by the response of the occupant to various environmental stimuli and by the integration of these inputs into a composite thermo-physical and comfort response. 
This section of the paper analyses the setup of a local punctual system with sufficient heating or cooling capability that can ensure a correction to the room level acclimatization system, which is necessary to improve the acclimatization conditions. On a thermal point of view, it allows to correct the local temperatures in the areas which are subject to solar irradiation through the glassed surfaces.

In the meantime, there may be conditions that cause different local temperatures with respect to the average value in a large open space environment. An acclimatization and air distribution system achieve excellence when it allows an effective punctual behavior that responds to any external disturbance and allows keeping almost constant comfort levels in any position inside the large environment. It achieves these goals by the right combination of temperature, air movement and relative humidity, which are necessary to keep everywhere the optimal thermo-hygrometric conditions.

It must be remarketed the huge influence of radiant sources on comfort conditions because the radiant mean temperature of the surfaces of the environment has a much higher weight with respect to the environmental air temperature while determining the thermal load on the occupants and the consequent sensation of comfort.

The objective $\mathrm{f}$ this paper $\mathrm{s}$ to obtain optimal conditions for the comfort of the people inside the large open space environment. The use of a sensing system by airspeed sensors and Peltier cells temperature sensors can pilot an effective localized heat pump by active Peltier cells with electrical excitation. Such a system produces an effective intelligent air conditioning system that can perfectly respond to the localized need inside a mesh of the large environment such as the one which has been presented in Figure 1.

The sensors measure the local $\mathrm{T}_{\mathrm{MRL}}$ and send a signal to the air vents, which govern the air speed in the air vents.

This intelligent system allows to obtain, in addition to local comfort conditions, a considerable energy saving. The increase in thermal load due to radiant exchanges near the glazed surfaces is certainly not felt in the points of the environment located at notable distance from surface radiant as shown in the graphs in Fig.3/a and Fig.3/b.

In Fig. 5, are shown the colored values of the PMV, in the points of the environment " $\mathrm{i}$ " of the open space environment. These are being obtained with the four possible adjustments of the automation plant

a) Air velocity $v_{a}=0,15 \mathrm{~m} / \mathrm{s}$ and air temperature, $T_{a}=26{ }^{\circ} \mathrm{C}(\mathrm{Tab} .1, \mathrm{I}=500)$

b) Air velocity $v_{a}=0,25 \mathrm{~m} / \mathrm{s}$ and air temperature, $T_{a}=26^{\circ} \mathrm{C}$ (Tab. $\left.1, \mathrm{I}=500\right)$

c) Air flow temperature, $T_{a}=24^{\circ} \mathrm{C}$ and $v_{a}=0,15 \mathrm{~m} / \mathrm{s}$

d) Air flow temperature, $T_{a}=24{ }^{\circ} \mathrm{C}$ and $v_{a}=0,25 \mathrm{~m} / \mathrm{s}$

Therefore this system does not require an increase of the thermal load of the centralized system, but only local interventions that can also be obtained with local devices such as Peltier-cells, which are placed on the perimeter surface in glass-wall, which act, on sensor information of the heat pumps o refrigerators, providing the required the local thermal load at that moment.

The open-space office environment (Figure 1 and 8 ) is characterized by a continuous glassed envelope surface and an air conditioning plant with modulated air-speeds by adjustable vents. The results of the simulation have been presented for the summer period. We consider the map of sensors, which is presented in Figure 1. Table 1 reports the physical values and comfort related values for each sensor "i". The local mean radiant temperatures, $T_{m r l}$ have been calculated with the related values of PMV and PPD.

Figure 8 and Figure 9 show the trends of the PMV and PPD, versus of the distance between the point and the radiating surface for two air velocity 0,15 and $0.25 \mathrm{~m} / \mathrm{s}$.

Table 1. Values of the $t_{a}, t_{m r l}, P M V$ and PPD, for persons standing, for $\mathrm{Va}=0.15$ and $0,25 \mathrm{~m} / \mathrm{s}$

\begin{tabular}{|c|c|c|c|c|c|c|c|c|c|}
\hline \multirow{2}{*}{\multicolumn{2}{|c|}{ Punti i }} & 1 and 4 & 2 and 3 & 5 and 8 & 6 and 7 & 9 and & 10 and & 13 and 16 & 14 and 15 \\
\hline & & & & & & 12 & 11 & & \\
\hline \multicolumn{2}{|r|}{$t_{3}$} & 26,0 & 26,0 & 26,0 & 26,0 & 26,0 & 26,0 & 26,0 & 26,0 \\
\hline \multirow[t]{2}{*}{$t_{\mathrm{m}}$} & $T_{p}=60$ & 37.2 & 37.2 & 30.5 & 30.8 & 28.7 & 28.7 & 27.6 & 27.7 \\
\hline & $I=500$ & 35.5 & 35.6 & 29.8 & 30,1 & 28,3 & 28,3 & 27,4 & 27,4 \\
\hline \multirow[t]{2}{*}{ PMV } & $T_{p}=60$ & 1,99 & 1.99 & 0,96 & 1,01 & 0,70 & 0,70 & 0,54 & 0,55 \\
\hline & $I=500$ & 1,73 & 1,74 & 0,86 & 0,90 & 0,64 & 0,64 & 0,51 & 0,51 \\
\hline \multirow[t]{2}{*}{ PPD\% } & $T_{p}=60$ & 76 & 76 & 25 & 26 & 15 & 15 & 11 & 11 \\
\hline & & 63 & 64 & 23 & 22 & 14 & 14 & 10 & 10 \\
\hline \multirow[t]{2}{*}{ PMV } & $T_{\alpha}=60$ & 1.33 & 1.33 & 0,48 & 0.52 & 0,27 & 0,27 & 0,15 & 0,15 \\
\hline & & 1.10 & 1.12 & 0.40 & 0.43 & 0.23 & 0.23 & 0.13 & 0.13 \\
\hline \multirow[t]{2}{*}{ PPD\% } & $T_{Q}=60$ & 42 & 42 & 10 & 11 & 7 & 7 & 5 & 5 \\
\hline & & 31 & 31 & 8 & 9 & 6 & 6 & 5 & 5 \\
\hline
\end{tabular}

Using photovoltaic cells connected to a TE heat pump system, the flow of heat on a surface can be controlled and the solution integrated into the building structure. Figure 9/B and 9/B show that increasing the distance from the radiant glassed surface improve the comfort conditions
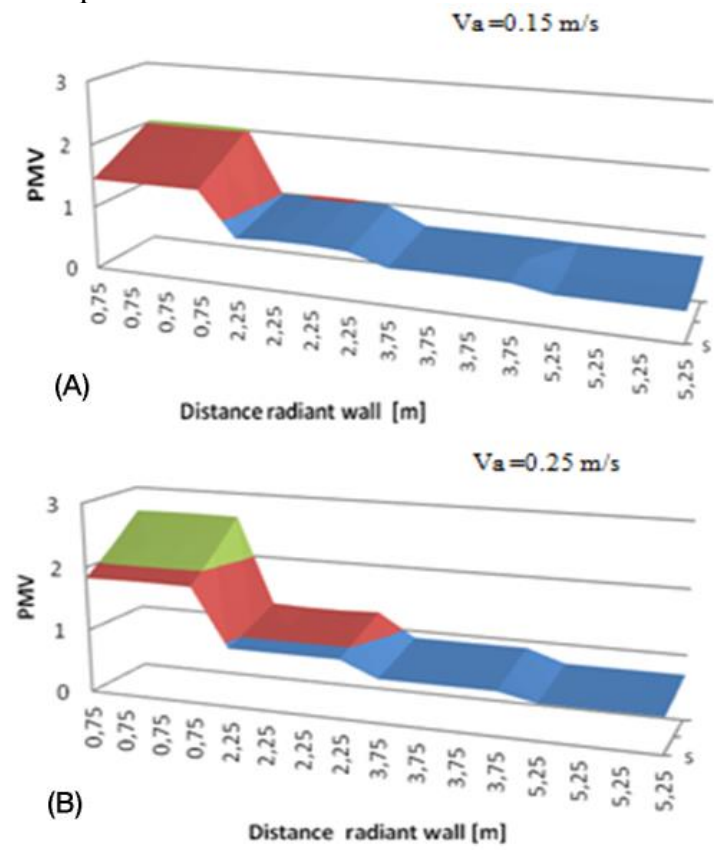

Figure 9. Values of the PMV versus the distance

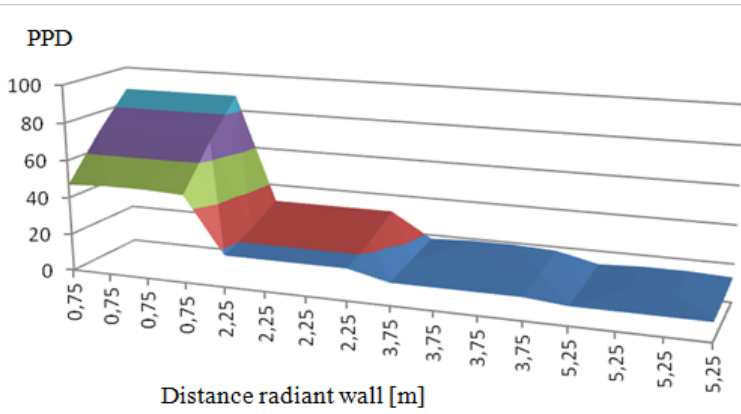

Figure 10. Values of the PPD versus the distance 
Figure 10 presents PPD (percentage of dissatisfaction) at an environmental airspeed $\mathrm{v}_{\mathrm{a}}=0.15 \mathrm{~m} / \mathrm{s}$ and $\mathrm{v}_{\mathrm{a}}=0.25 \mathrm{~m} / \mathrm{s}$. It can be observed that the percentage of dissatisfaction decreases from an average $30 \%$ to about $10 \%$ as the distance increases from the solar heated glass.

Table 2. Comparison values of PMV and PMV'

\begin{tabular}{|c|c|c|c|c|c|c|c|c|}
\hline Pointi & 14 & 2 and 3 & 5 and 8 & 6 and 7 & 9 and 12 & 10 and 11 & 13 and 16 & 14 and 15 \\
\hline PMV $a=0,7$ & 2.20 & 2,20 & 1,08 & 1,08 & 1,78 & 0,78 & 0,62 & 0,62 \\
\hline PMV' $\quad \mathrm{a}=0,7$ & 1,21 & 1,21 & 1,21 & 1,21 & 1,21 & 1,21 & 1,21 & 1,21 \\
\hline Diff\% a $=0,7$ & 45,0 & 45,5 & $-12,1$ & $-12,1$ & $.55,1$ & $-55,1$ & $.95,1$ & $.95,1$ \\
\hline PMV $I=500$ & 1,83 & 1,84 & 0,92 & 0,92 & 0,68 & 0,68 & 0,56 & 0,56 \\
\hline PMV' $I=500$ & 1,07 & 1,07 & 1,07 & 1,07 & 1,07 & 1,07 & 1,07 & 1,07 \\
\hline Diffe\% $I=500$ & 41,5 & 41,8 & $-16,3$ & $-16,3$ & $.57,5$ & $.57,5$ & 91,1 & $.91,1$ \\
\hline
\end{tabular}

Table 2 shows the comparison between the values of PMV, reported in Table 1, and values of PMV', obtained with $\mathrm{T}_{\mathrm{mr}}$ calculated using the eq.1) and the percentage error calculated by equation (6):

$$
\text { Diff } \%=\frac{P M V-P M V^{\prime}}{P M V} x 100
$$

The Figure (11) shows the error between PMV and PMV' calculated by equation 6 , versus the distance $d_{i}$ of the points " $i$ " from the radiating surface.

It shows clearly the influence of the distance on the wellness conditions and that the wellness conditions are incremented by the distance. In addition, $t$ can be observed that the difference between PMV and PMV' changes its sign and increases considerably.

A prototype thermoelectric cooler can integrate the system centralized of air conditioning.

The prototype can use UT8-12-40-RTV thermoelectric modules Bismuth Telluride thermo-elements [41].
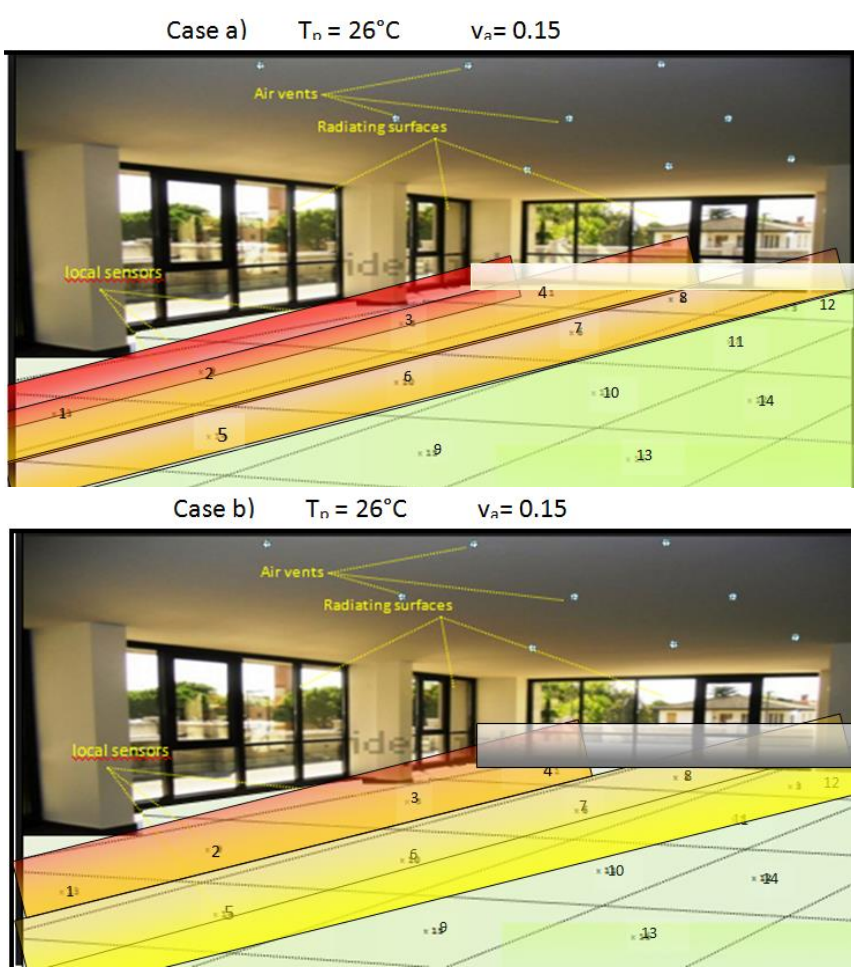
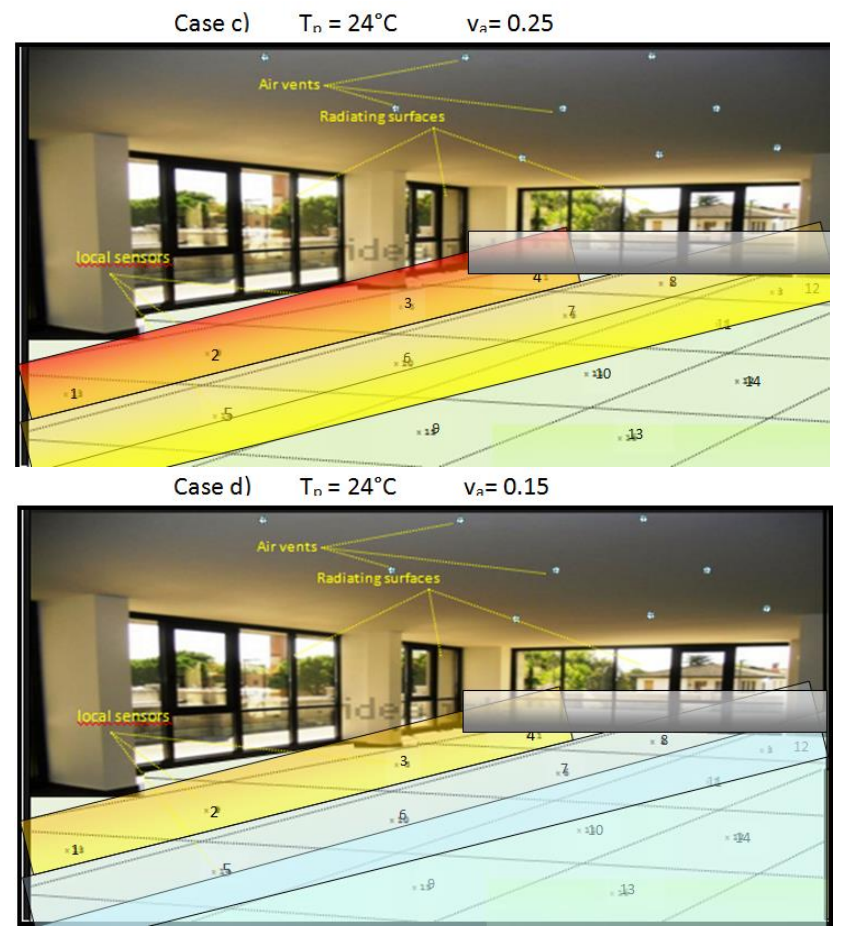

Figure 11. Colored maps of the wellness conditions of the considered environment

TE modules can constitute micro-units made up of $8 \mathrm{TE}$ devices with a parallel electrical connection of four strings of two modules in series $(2 \mathrm{Sx} 4 \mathrm{P})$ see Fig.5. Eight fans, with a power of $3 \mathrm{~W}$ each, can be placed on the hot side to remove the heat produced by forced convection. On the cold side a blower forces the air on the heat exchanger through a duct. Another way to use TE modules for air conditioning, is to use of the "Active Building Envelopes" or ABE.

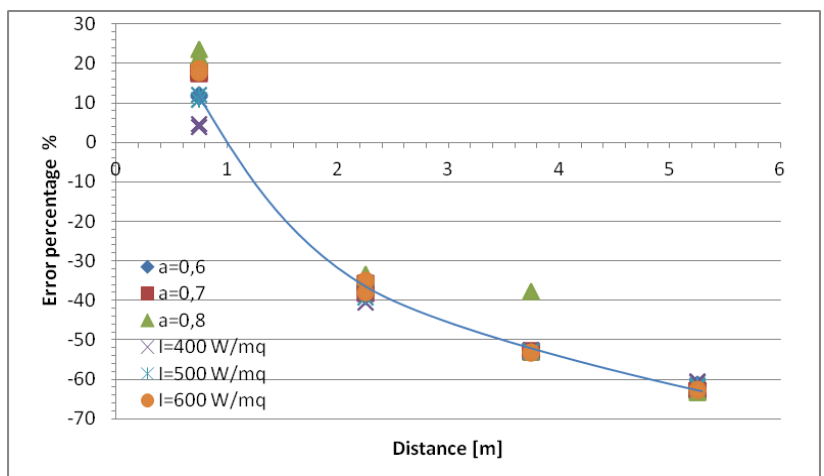

Figure 12. Percentage errors calculated with the eq.3), between PMV and PMV', versus the distance

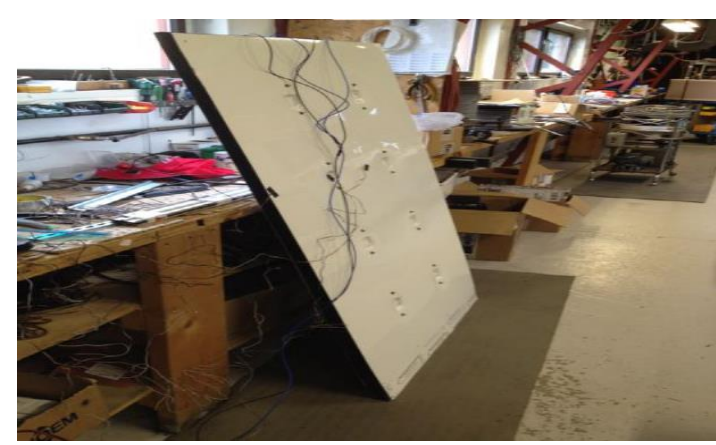

Figure 13. Picture of prototype wall of the $8 \mathrm{TE}$ 
Such systems can use PV cells to transform solar energy into electrical energy that is used to power a TE heat pump system. Both systems are integrated in a surface closed, and the system can operate in both heating and cooling modes depending on the direction of the current. ABE systems can actively use solar energy to maintain a temperature gradient on a material surface, compensating for passive heat transfer through walls with heat transfer from the TE system [31]. The prototype of this study was tested in different ways at the Renesselaer Polytechnic Institute of New York.

\section{CONCLUSIONS}

This paper has started an analysis of the effect that can be produced on wellness conditions by the presence of large radiant heat sources (such as large glassed envelope facades) during summertime. It has demonstrated that the average evaluation at room value is not sufficient to describe the discomfort which is produced in large open space working environments because of the presence of large glassed surfaces In this case the comfort parameters, which can be determined by average values, are not representative of the real wellness conditions in the area of the room rear he glassed surfaces. This lack of fidelity is a consequence of the prominence of the radiant exchanges, which produces a large influence on the local comfort conditions that depends on the position of the point in which the parameter is evaluated.

It is Proposed an intervention on the automation system of the air plant conditioning, with sensors local radiant temperature, type Wi-Fi, which regulate the speed of the air vents and a control system which regulates the flow temperature, in order to obtain in every point of the room "open-space" optimal, comfort conditions and air quality and a remarkable energy saving [24-29].

Evaluations conducted through the cases a) and b), given in Figs. 3/a, 3/b, and Fig.5 for the four cases, they have shown how a simple intervention on air speed sent from the vents, allows to obtain an intelligent control of the system, making it economical and versatile to the dynamic needs of the environment. If the control system requires a greater air velocity, the limits imposed by the regulations, it is recommended an effective intervention on the air flow temperature that corrects it of some degree and allows obtaining the optimal local conditions.

They modify of the air temperature from the air vents, requires some more difficulties with respect to the traditional single speed adjustment, in such situations - cases c) and d) for a better management of the system-plant. It is more appropriate reduce the flow temperature of the air (by $26^{\circ} \mathrm{C}$ to $24^{\circ} \mathrm{C}$ ) and then if necessary to intervene on the speed of the nozzle by varying the air velocity $\mathrm{v}_{\mathrm{a}}=0.15 \mathrm{~m} / \mathrm{s}$ (case c), $\mathrm{v}_{\mathrm{a}}=0.25 \mathrm{~m} / \mathrm{s}$ (case $\mathrm{d}$ ).

Local interventions can be obtained with devices such as Peltier cells, sites on the glass surfaces of the wall, which act on the local sensor's information - of the heat pumps or refrigerators, providing the required thermal load local.

The visual observation of the four cases (Figure11) shows clearly the effects of possible adjustments of the system.

That in the case d), all of the open-space environment the points have the same optimum conditions. The effect of the high performance of glazing types (i.e. low-e double glazing, selective glazing, reflective glazing, etc. which are now commercially available) on the condition thermal comfort should be object of the next studies and future works.

\section{REFERENCES}

[1] Pérez-Lombard L, Ortiz J, Pout C. (2008). A review on buildings energy consumption information. Energy and Buildings $\quad 40(3)$ : 394-398. https://doi.org/10.1016/j.enbuild.2007.03.007

[2] Patterson MG. (1996). What is energy efficiency? Concepts, indicators and methodological issues. Energy Policy 24(5): 377-390. https://doi.org/10.1016/03014215(96)00017-1

[3] Givoni B. (1992). Comfort, climate analysis and building design guidelines. Energy and Buildings 18(1): 11-23. https://doi.org/10.1016/0378-7788(92)90047-K

[4] Gram-Hanssen K. (2010). Residential heat comfort practices: understanding users. Building Research \& Information 38(2): 175-186. https://doi.org/10.1080/09613210903541527

[5] Humphreys MA, Nicol JF. (1998). Understanding the adaptive approach to thermal comfort. ASHRAE Transactions 104: 991.

[6] Djongyang N, Tchinda R, Njomo D. (2010). Thermal comfort: A review paper. Renewable and Sustainable Energy Reviews 14(9): 2626-2640. https://doi.org/10.1016/j.rser.2010.07.040

[7] Schiller G, Arens EA, Bauman F, Benton C, Fountain M, Doherty T. (1988). A field study of thermal environments and comfort in office buildings. ASHRAE Transactions.

[8] Marvuglia A, Messineo A, Nicolosi G. (2014). Coupling a neural network temperature predictor and a fuzzy logic controller to perform thermal comfort regulation in an office building. Building and Environment 72: 287-299. https://doi.org/10.1016/j.buildenv.2013.10.020

[9] Hwang RL, Shu SY. (2011). Building envelope regulations on thermal comfort in glass facade buildings and energy-saving potential for PMV-based comfort control. Building and Environment 46(4): 824-834. https://doi.org/10.1016/j.buildenv.2010.10.009

[10] Bessoudo M, Tzempelikos A, Athienitis AK, Zmeureanu R. (2010). Indoor thermal environmental conditions near glazed facades with shading devices-Part I: Experiments and building thermal model. Building and Environment 45(11): https://doi.org/10.1016/j.buildenv.2010.05.013

[11] Tzempelikos A, Bessoudo M, Athienitis AK, Zmeureanu R. (2010). Indoor thermal environmental conditions near glazed facades with shading devices-Part II: Thermal comfort simulation and impact of glazing and shading properties. Building and Environment 45(11): 25172525. https://doi.org/10.1016/j.buildenv.2010.05.014

[12] Cappelletti F, Prada A, Romagnoni P, Gasparella A. (2014). Passive performance of glazed components in heating and cooling of an open-space office under controlled indoor thermal comfort. Building and Environment 72: 131-144. https://doi.org/10.1016/j.buildenv.2013.10.022

[13] Lyons PR, Arasteh D, Huizenga C. (2000). Window performance for human thermal comfort. ASHRAE Transactions 106(1): 594-604.

[14] Cannistraro G, Cannistraro M, Restivo R. (2015). Some observations on the radiative exchanges influence on thermal comfort in rectangular open-space environments. 
Intl. Journal of Heat \& Technology 33: 79-84. https://doi.org/10.18280/ijht.330213

[15] da Graça GC, Augusto A, Lerer MM. (2012). Solar powered net zero energy houses for southern Europe: Feasibility study. Solar Energy 86(1): 634-646. https://doi.org/10.1016/j.solener.2011.11.008

[16] Huang C, Zhou ZJ, Li ML, Li W, Huang WG, Yang JG, Xiao XQ. (2007). Measurements of indoor thermal environment and energy analysis in a large space building in typical seasons. Building and Environment 42(5): https://doi.org/10.1016/j.buildenv.2006.02.016

$1869-1877$

[17] Posner JD, Buchanan CR, Dunn-Rankin D. (2003). Measurement and prediction of indoor air flow in a model room. Energy and Buildings 35(5): 515-526. https://doi.org/10.1016/S0378-7788(02)00163-9

[18] Haapio A, Viitaniemi P. (2008). A critical review of building environmental assessment tools. Environmental Impact Assessment Review 28(7): 469-482. https://doi.org/10.1016/j.eiar.2008.01.002

[19] Akimoto T, Tanabe SI, Yanai T, Sasaki M. (2010). Thermal comfort and productivity-Evaluation of workplace environment in a task conditioned office. Building and Environment 45(1): 45-50. https://doi.org/10.1016/j.buildenv.2009.06.022

[20] La Gennusa M, Nucara A, Rizzo G, Scaccianoce G. (2005). The calculation of the mean radiant temperature of a subject exposed to the solar radiation - a generalised algorithm. Building and Environment 40(3): 367-375. https://doi.org/10.1016/j.buildenv.2004.06.019

[21] Sullivan R. (1986). Thermal comfort in the LRI study. "International Memorandum/Report, Window and Daylighting Group, Lawrence Berkeley National Laboratory, CA, USA.

[22] Hwang RL, Shu SY. (2011). Building envelope regulations on thermal comfort in glass facade buildings and energy-saving potential for PMV-based comfort control. Building and Environment 46(4): 824-834.

[23] Mazzei P, Minichiello F, Palma D. (2005). HVAC dehumidification systems for thermal comfort: a critical review. Applied Thermal Engineering 25(5-6): 677-707.

[24] Goodfellow HD. (2001). Industrial ventilation design guidebook. Elsevier.

[25] Schiller G, Arens EA, Bauman F, Benton C, Fountain M, Doherty T. (1988). A field study of thermal environments and comfort in office buildings. Ashrae Transactions.

[26] ISO 7730 (2006). Moderate thermal environmentsdetermination of the PMV and PPD indices and specification of the conditions for thermal comfort. Intern. Standards Organ., Geneve.

[27] ISO, ISO Standard 7726. (2002). Ergonomics of the thermal environment-Instruments for measuring physical quantities. Inter. Standard Org., Geneve.

[28] Rizzo G, Franzitta G, Cannistraro G. (1991). Algorithms for the calculation of the mean projected area factors of seated and standing persons. Energy and Buildings 17(3): 221-230. https://doi.org/10.1016/0378-7788(91)90109$\mathrm{G}$

[29] Cannistraro G, Franzitta G, Giaconia C, Rizzo G. (1992). Algorithms for the calculation of the view factors between human body and rectangular surfaces in parallelepiped environments. Energy and Buildings 19(1): $\quad 51-60 . \quad$ https://doi.org/10.1016/03787788(92)90035-F
[30] La Gennusa M, Nucara A, Rizzo G, Scaccianoce G. (2005). The calculation of the mean radiant temperature of a subject exposed to the solar radiation - a generalised algorithm. Building and Environment 40(3): 367-375.

[31] Chaiyapinunt S, et al. (2005). Performance rating of glass windows and glass windows with films in aspect of thermal comfort and heat transmission. Energy and Buildings $37(7)$ : 725-738. https://doi.org/10.1016/j.enbuild.2004.10.008

[32] Atmaca I, Kaynakli O, Yigit A. (2007). Effects of radiant temperature on thermal comfort. Building and Environment $\quad 42(9)$ : $3210-3220$. https://doi.org/10.1016/j.buildenv.2006.08.009

[33] La Gennusa M, Nucara A, Pietrafesa M, Rizzo G. (2007). A model for managing and evaluating solar radiation for indoor thermal comfort. Solar Energy 81(5): 594-606. https://doi.org/10.1016/j.solener.2006.09.005

[34] Chan MY, Mak CW. (2008). Thermal comfort levels in a room with solar radiation. Indoor and Built Environment 17(6): 516-524. https://doi.org/10.1177/1420326X08097388

[35] Cucumo M, De Rosa A, Ferraro V, Kaliakatsos D, Marinelli V. (2008). Correlations of global and diffuse solar luminous efficacy for all sky conditions and comparisons with experimental data of five localities. Renewable Energy 33(9): 2036-2047. https://doi.org/10.1016/j.renene.2007.11.015

[36] Khamporn N, Chaiyapinunt S. (2014). An investigation on the human thermal comfort from a glass window. Engineering Journal (Eng. J.) 18(1): 25-44. https://doi.org/10.4186/ej.2014.18.1.25

[37] Cannistraro G, Cannistraro M, Restivo R. (2015). Smart control of air climatization system in function on the values of mean local radiant temperature. Smart Science 3(3):

157-163. http://dx.doi.org/10.6493/SmartSci.2015.331

[38] Goldsmid HJ. (2016). Theory of Thermoelectric Refrigeration and Generation. In Introduction to Thermoelectricity. Springer, Berlin, Heidelberg, 9-24. https://doi.org/10.1007/978-3-662-49256-7 13

[39] Fanger PO. (1970). Thermal comfort. Analysis and applications in environmental engineering. Thermal comfort. Analysis and applications in environmental engineering.

https://www.cabdirect.org/cabdirect/abstract/197227002 68

[40] Cannistraro G, Cannistraro M, Restivo R. (2015). The local media radiant temperature for the calculation of comfort in areas characterized by radiant surfaces. IJH\&T 33: 115-122. https://doi.org/10.18280/ijht.330116

[41] Laird Inc., Caltagirone JP. (1975). Thermoconvective instabilities in a horizontal porous layer. J. Fluid Mech. 72(2): 269-287. https://doi.org/10.1017/S0022112075003345

\section{NOMENCLATURE}

$\begin{array}{ll}\mathrm{T}_{\mathrm{a}} & \text { Air temperature, }\left[{ }^{\circ} \mathrm{C}\right] \\ \mathrm{v}_{\mathrm{a}} & \text { Air velocity, }[\mathrm{m} / \mathrm{s}] \\ \varphi_{\mathrm{a}} & \text { Air humidity, dimensionless } \\ \mathrm{T}_{\mathrm{op}} & \text { Operative temperature, }\left[{ }^{\circ} \mathrm{C}\right] \\ \mathrm{T}_{\mathrm{mr}} & \text { Mean radiant temperature, }\left[{ }^{\circ}\right]\end{array}$


Shy $\quad$ Surface j-th wall, $\left[\mathrm{m}^{2}\right]$

$\mathrm{T}_{\mathrm{mrl}} \quad$ Local Mean radiant temperature, $\left[{ }^{\circ} \mathrm{C}\right]$

$\mathrm{T}_{\mathrm{j}}$ temperature $\mathrm{j}$-th wall, $\left[{ }^{\circ} \mathrm{C}\right]$

Iclo Resistenza termica abbigliamento, [clo]

Met metabolic activity, Met

PMV Predicted Mean Vote, [-]

$\mathrm{PMV}_{\mathrm{m}} \quad$ Predicted Mean Vote, medium, [-]

I Incident solar radiation on the glass surface, $\left[\mathrm{W} / \mathrm{m}^{2}\right]$

A Absorption coefficient glass wall, [-]

$\mathrm{F}_{\mathrm{i}, \mathrm{j}} \quad$ Factor of view of a subject site in the point "i" respect to the walls, [-]

$\mathrm{f}_{\text {api }} \quad$ Factor projected area of the subject compared to surfaces, [-] distance of the point of the environment, respect to the into wall, [m]

Colored Ranges of the PMV and Physical sensation

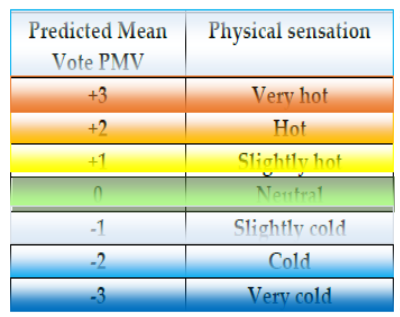

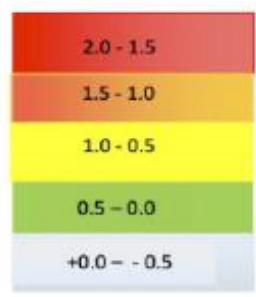

